\title{
Biological aspects of Leucothyreus alvarengai Frey and Leucothyreus aff. semipruinosus Ohaus (Coleoptera, Melolonthidae, Rutelinae) in crop succession at central Brazil
}

\author{
Alex Furquim Pereira ${ }^{1}$, Sérgio Roberto Rodrigues ${ }^{1} \&$ Miguel Angel Morón $^{2}$
}

\author{
${ }^{1}$ Universidade Estadual de Mato Grosso do Sul, Rodovia Aquidauana/CERA, km 12, 79200-000 Aquidauana-MS, Brasil. \\ alex_furquim@hotmail.com,sergio@uems.br \\ ${ }^{2}$ Red de Biodiversidad y Sistemática, Instituto de Ecologia, A.C Apdo. Postal 63, Xalapa, Veracruz, 91000, México. \\ moronrios.miguelangel@gmail.com
}

\begin{abstract}
Biological aspects of Leucothyreus alvarengai Frey and Leucothyreus aff. semipruinosus Ohaus (Coleoptera, Melolonthidae, Rutelinae) in crop succession at central Brazil. Beetles of the family Melolonthidae make up a large group and some species are considered pests of planted crops. Little information is available on the basic biological aspects of the genus Leucothyreus, such as association with cultivated crops and their occurrence periods. Therefore studies were developed in soybean and corn crops in Tangará da Serra, Mato Grosso, Brazil, with the objective of studying the occurrence and biological aspects of Leucothyreus alvarengai Frey and Leucothyreus aff. semipruinosus Ohaus. For acquisition of immature specimens of both species, in April 2011 sampling was performed in corn fields, in July and October in the fallow area, and in soybeans fields planted in December; in 2012 sampling was performed in January and February in soybean fields and in March in corn fields. In 2011 the total number of larvae obtained in April, July, October and December were 100, 6, 30 and 27, and in January, February and March of 2012 these quantities were 32, 52 and 65 larvae, respectively. In all sampling events the larvae of L. alvarengai were collected in greater quantity. At the beginning of the reproductive period of $L$. alvarengai and $L$. aff. semipruinosus, it was observed that the adults began to fly and soon after started oviposition in the field in September. The appearance of larvae coincides with the time of soybean planting in the field, thus the larvae feed on roots of soybean plants at the beginning of their development and the cycle from egg to adult of the two species was completed in one year.
\end{abstract}

KEYWORDS. Biology; Geniatini; Insecta; white grub.

Melolonthidae is represented by several species which may be crop pests due to the damage they cause (Oliveira et al. 2008; Rodrigues et al. 2011). They feed mainly on the root system, causing yellowing, followed by wilting and subsequent death of the plants (Oliveira et al. 2004). Among these insects, highlighted are those that feed on economically important crops such as soybeans, corn, sugarcane and wheat.

In Melolonthidae some species such as those of the genus Leucothyreus Macleay, 1819 stand out as pests and are reported causing damage to crops in regions of South America. In northern Cauca, Colombia, Pardo-Locarno et al. (2005) considered Leucothyreus sp. as pests of the roots of plants in agroecological systems. Pardo-Locarno et al. (2006) reported Leucothyreus femoratus Burmeister, 1844, in Colombia, as agriculturally important, both in their larval and adult phases.

In Brazil, Puker et al. (2011) reported the occurrence of Leucothyreus albopilosus Ohaus, 1917 feeding on lesions on the stem of Eucalyptus citriodora Hook, 1848 in Mato Grosso do Sul. Puker et al. (2009) also observed in Mato Grosso do Sul, larvae of Leucothyreus sp. and Leucothyreus dorsalis Blanchard, 1850 associated with root systems of the palm Acrocomia aculeata (Jacq) Lodd. ex Mart. Information on the biological aspects and period of occurrence of $L$. dorsalis were studied by Rodrigues et al. (2010a).
There is little information on the association of specimens of Leucothyreus with important crops in Brazil, existing information dealing mostly with associations involving other beetle genera. Oliveira et al. (2000) reported on the occurrence of Phyllophaga cuyabana Moser, 1918 causing damage in soybean crops in the state of Paraná, Brazil. In areas of Cerrado, in the Federal District, $P$. aff. capillata Blanchard, 1850 was encountered causing damage to soybean crops (Oliveira et al. 2007).

Cyclocephala forsteri Endrodi, 1963 has been reported causing damage in soybean crops in the Brazilian state of Mato Grosso do Sul (Santos \& Ávila 2007). Rodrigues et al. (2011) observed Liogenys fuscus Blanchard, 1851as the main Melolonthidae pest species associated with certain crops, including corn and soybeans. In Rio Grande do Sul, Silva \& Costa (2002) observed Diloboderus abderus Sturm, 1826 as a pest in corn crops.

Given the limited information on species of the genus Leucothyreus associated with cultivated crops in Brazil, studies were developed on soybeans and corn in Tangará da Serra, Mato Grosso, Brazil, with the objective of studying the occurrence and biological aspects of Leucothyreus alvarengai Frey, 1976 and Leucothyreus aff. semipruinosus Ohaus, 1917. 


\section{MATERIAL AND METHODS}

To sample and monitor the occurrence of immature stages of $L$. alvarengai and $L$. aff. semipruinosus, studies were conducted in the crop area of the Três Irmãos farm, located approximately $18 \mathrm{~km}$ from the city of Tangará da Serra, Mato Grosso, at $14^{\circ} 72^{\prime} \mathrm{S}$ and $57^{\circ} 56^{\prime} \mathrm{W}$. The climate in this region is Aw according to the Köppen-Geiger classification (tropical rainy), with dry winter and wet summer, rainfall ranging from 1,300 to $2,000 \mathrm{~mm} . \mathrm{yr}^{-1}$ and temperatures varying from 16 to $38^{\circ} \mathrm{C}$ (Maman et al. 2007). In this location the crop succession system is used, with soybeans in the summer and corn in the off-season. In the 2010/2011 and 2011/2012 growing seasons the soybean variety Nidera AN 8500 and the hybrid corn Dow 2B688 were planted in the experimental area. The crop fields had approximately 120 hectares, where one field was used to conduct the studies.

In 2011, samplings of larvae of Leucothyreus were conducted in corn in April, and sampling was performed again in July and October, but the experimental area was fallow; sampling was again performed in December, when the soybean culture was already installed. In 2012 samples were collected in January and February in soybeans and in March in corn fields.

Larvae samples were taken randomly in the experimental area. Each month, when taking the samples, 50 trenches were excavated in the crop rows, where each trench measured $25 \times 25 \times 30 \mathrm{~cm}$ deep (adapted from the methodology described by Pardo-Locarno et al. 2005). When digging trenches the larvae were obtained and kept in separate 500 $\mathrm{ml}$ plastic containers with soil.

The larvae sampled were taken to the laboratory of Entomology of the State University of Mato Grosso do Sul, in Aquidauana, MS, Brazil, where they were maintained in individual $500 \mathrm{ml}$ plastic containers, and reared until reaching adulthood. Roughly two-thirds of the plastic containers were filled with soil and a seedling of Brachiaria decumbens Stapf, until the larvae reached adulthood. Seedlings of $B$. decumbens were replaced biweekly, thus providing roots for the larvae to feed on.

From observing the raster of the larvae, they were separated for study of biological aspects. The larvae were measured weekly, assessing the width of the head capsule, length and width of the larvae (Silva \& Grützmacher 1996; Rodrigues et al. 2008). In the pre-pupal and pupal phases they were weighted as well. Adults were sexed and measured with calipers, along with the width of the prothorax and length of the body, followed by drying in an oven $\left(60 \pm 5^{\circ} \mathrm{C}\right)$ for 48 hours.

Identification of L. alvarengai and $L$. aff. semipruinosus was performed by comparing the material deposited in the Scarabaeoidea collection of the Institute of Ecology, Xalapa, Veracruz, Mexico (IEXA), with images of the type specimens deposited in the collection of Zoologische Museum der Humboldt Universität zu Berlin (ZMHU) and with the original descriptions. Specimens were mounted and deposited in the insect collection of the Entomology Laboratory at the State University of Mato Grosso do Sul in Aquidauana, MS, Brazil (UEMS), and at the Institute of Ecology in Xalapa, Veracruz, Mexico (IEXA).

\section{RESULTS AND DISCUSSION}

During the sampling conducted in April 2011 in the corn crop, 100 larvae were collected, being 69 of L. alvarengai and 31 of L. aff. semipruinosus. Leucothyreus alvarengai presented an average density of 23 larvae. $\mathrm{m}^{-2}$, while that of L. aff. semipruinosus was 10.3 larvae. $\mathrm{m}^{-2}$.

During samplings carried out in July the experimental area was fallow, and in this sample there was a decrease in the number of larvae, collecting a total of 6 which resulted in a mean density of 2.0 larvae. $\mathrm{m}^{2}$, all of $L$. alvarengai. The reduction in larval density may be related to the lack of rainfall in the region during the sampling period, which causes the larvae to migrate in the soil profile in search of moisture, or may also be related to the biological cycle of the species which migrate in the soil profile to construct a pupal chamber, however they have not been found in the deeper samples (unpubl. results).

In October the area was still fallow, however the number of larvae sampled increased to 30 larvae, of which 22 were L. alvarengai and eight were $L$. aff. semipruinosus, resulting in mean densities of 7.3 larvae. $\mathrm{m}^{-2}$ and 2.7 larvae.m ${ }^{-2}$, respectively. The increase in number of larvae may be due to the onset of rains in September, so that adults of Leucothyreus take flight and begin oviposition in the experimental area and in October the first instar larvae begin to be found.

In December, 27 larvae were sampled in soybeans, and of these 18 were of $L$. alvarengai and nine of $L$. aff. semipruinosus, which generated a density of 6.0 and 3.0 larvae. $\mathrm{m}^{-2}$, respectively. Sampling conducted in soybeans in January 2012 obtained 32 larvae, 19 of L. alvarengai and 13 of $L$. aff. semipruinosus, with average densities of 6.3 larvae. $\mathrm{m}^{-2}$ and 4.3 larvae. $\mathrm{m}^{-2}$, respectively. In February 52 Leucothyreus larvae were sampled in soybeans, of which 32 were $L$. alvarengai and 20 were $L$. aff. semipruinosus, with an average densities of 10.7 and 6.7 larvae. $\mathrm{m}^{-2}$, respectively. In March, 65 larvae were sampled in corn, being 42 of $L$. alvarengai and of 23 L. aff. semipruinosus with densities of 14 larvae. $\mathrm{m}^{-2}$ and 7.7 larvae. $\mathrm{m}^{-2}$ on average. The Leucothyreus larvae encountered remained near the roots of soybean and corn which they feed on.

High densities of larvae of phytophagous Scarabaeoidea were found in some cultures. Coutinho et al. (2011) sampled 53.65 larvae. $\mathrm{m}^{-2}$ in sugarcane. In soybeans, Oliveira et al. (1997) collected on average 20 larvae. $\mathrm{m}^{-2}$ of $P$. cuyabana.

Differentiation of the third instar larvae of Leucothyreus alvarengai and $L$. aff. semipruinosus can be performed through observation of some characters. In L. alvarengai the width of the head capsule is $3.3 \mathrm{~mm}$, body length of 22.9 $\mathrm{mm}$ and thorax width of $4.7 \mathrm{~mm}$; two large and three small dorsoepicranial setae in each side of the epicranial suture; 
raster with three pali on each palidium (Fig. 1a). In $L$. aff. semipruinosus the width of the head capsule is $4.1 \mathrm{~mm}$, body length of 24.6 and thorax width of $5.0 \mathrm{~mm}$; two large dorsoepicranial setae in each side of the epicranial suture; raster with four to five pali on each palidium (Fig. 1b). The observation of palidia is an important tool for species differentiation of larvae of Scarabaeoidea. In a study conducted by Coutinho et al. (2011), chaeotaxy on the raster were used as one of the morphological characteristics for differentiation of species collected in sugarcane fields.
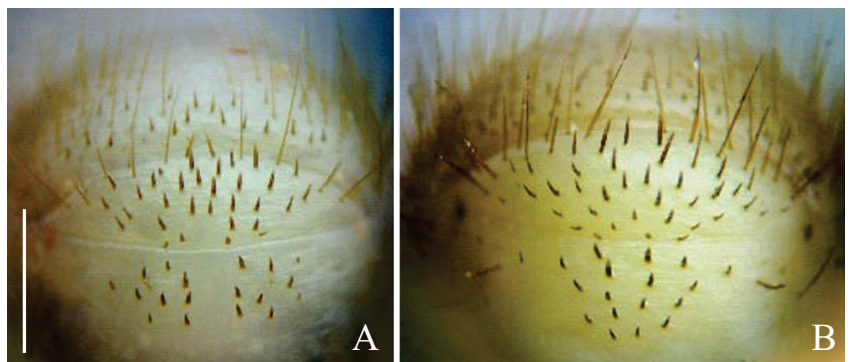

Fig. 1. Image of the raster of Leucothyreus alvarengai Frey (A) and Leucothyreus aff. semipruinosus Ohaus (B) (scale $1 \mathrm{~mm}$ ).

Additional morphological features used for differentiation of species were observed in adult males of Leucothyreus. In L. alvarengai body length is 9.8 to $10.6 \mathrm{~mm}$; dorsal coloration dark brown with iridescent reflections on pronotum, elytra shinny and legs yellowish brown; anterior border of clypeus almost semicircular; posterior angles of pronotum obtuse, not prominent; elytra with all longitudinal grooves clearly marked, posterior half of elytral surface less convex than anterior half; aedeagus with both parameres small, short, narrow, symmetrical, phalobase with four projections, one on each side and two dorsal (Fig. 2).

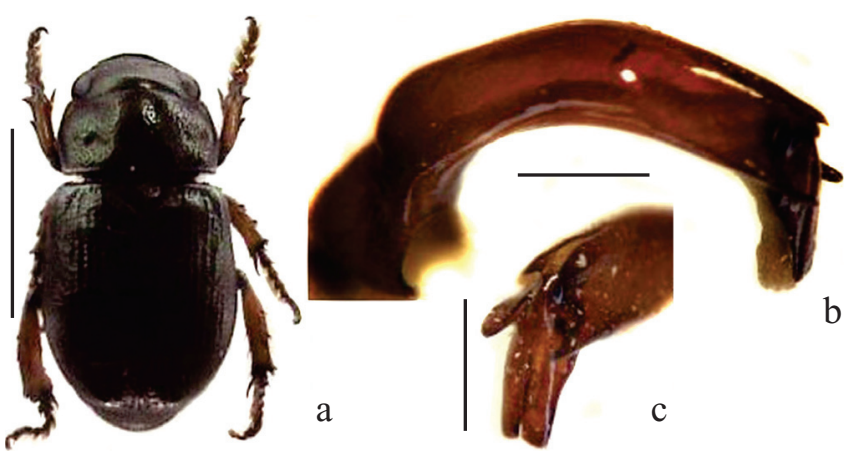

Fig. 2. Adult male of Leucothyreus alvarengai Frey (a) (scale $5 \mathrm{~mm}$ ), aedeagus from lateral (b) and front views (c) (scale $1 \mathrm{~mm}$ ).

In $L$. aff. semipruinosus, the body length is 10.5 to 11.8 $\mathrm{mm}$; dorsal coloration dark brown with sparse iridescent reflections on pronotum, elytra slightly opaque and legs brown; anterior border of clypeus semitrapezoidal with rounded cor- ners; posterior angles of pronotum almost straight, prominent; elytra with some longitudinal grooves weakly marked, posterior half of elytral surface more convex than anterior half (more noticeable in females); aedeagus with parameres long, very slender, asymmetrical, phalobase without projections (Fig. 3).

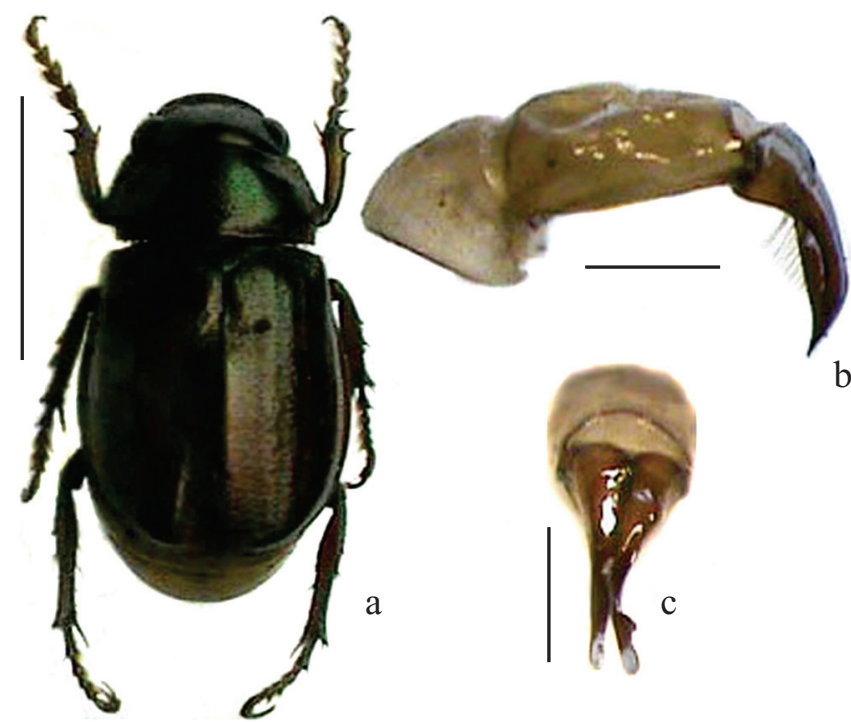

Fig. 3. Adult male of Leucothyreus aff. semipruinosus Ohaus (a) (scale 5 $\mathrm{mm}$ ), aedeagus from lateral (b) and front views (c) (scale $1 \mathrm{~mm}$ ).

Additional information on adult Leucothyreus is presented by Jameson \& Hawkins (2005), who reported that the adults of this genus generally present body size varying from 8.0 to $18.0 \mathrm{~mm}$, and that they are most frequently dark brown, black or metallic brown.

Biological aspects of Leucothyreus alvarengai. Adults usually begin to fly in the field in September and are observed until January, where this period coincides with the rainy season in the region of study. During the period of adult occurrence, eggs were also found, therefore the period in which the adults are flying may also be when oviposition is performed in the field (Fig. 4).

First instar larvae are found from September until early February, while the second instar are found beginning in October when the soybean crop had just been sown and can be sampled until early May, when the corn crop is still in the field. Larvae in the third instar begin to be collected in midNovember and are found until the end of July, being present during part of the soybean cycle and throughout the corn development cycle (Fig. 4).

First instar larvae collected in the field did not survive in the laboratory. Larvae of L. alvarengai in the second and third instar, when reared in the laboratory remained in these phases for 37.3 days and 53.3 days, respectively (Table I). The pre-pupal phase lasted for 55.0 days on average. The pupal stage lasted on average 24.2 days and in this stage they presented a yellowish color, where this color changed to 


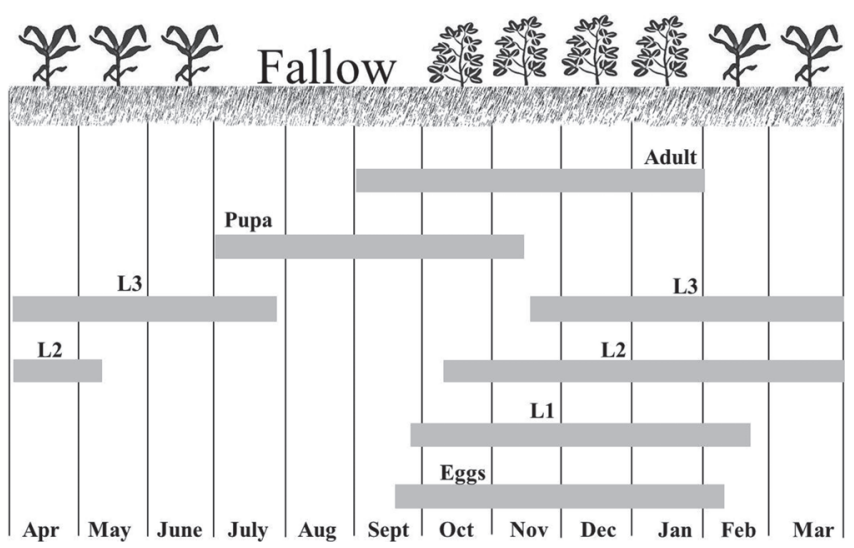

Fig. 4. Seasonality of development phases of Leucothyreus alvarengai Frey in crop succession between April 2011 and March 2012 in Tangará da Serra, Mato Grosso, Brazil.

brown at the end of development. In the adult phase $L$. alvarengai showed average longevity of 23.6 days. The biological cycle of the second instar until emergence of the adult reared in the laboratory was completed in 182.9 days on average (Table I).

Width of the head capsules of L. alvarengai was measured, obtaining mean width values for the second instar of $2.5 \mathrm{~mm}(\mathrm{n}=63)$ and that of the third instar was $3.3 \mathrm{~mm}(\mathrm{n}=$ 47 ), thus indicating a growth of the head capsules of 1.3 times. Second instar larvae of L. alvarengai presented average dimensions of $16.8 \mathrm{~mm}$ in length and $3.6 \mathrm{~mm}$ in width (Table II). In the third instar the larvae showed a mean length of $22.9 \mathrm{~mm}$ and $4.7 \mathrm{~mm}$ in width. Growth of 1.4 times in length and 1.3 times in width can be observed from the second to third instar. In the pre-pupal phase the L. alvarengai larvae weighed $311.3 \mathrm{mg}$ on average $(\mathrm{n}=37)$, and in the pupal stage the mean weight was $202.0 \mathrm{mg}(\mathrm{n}=32)$. Pupae of $L$. alvarengai showed a mean length of $11.8 \mathrm{~mm}$ and $5.3 \mathrm{~mm}$ in width. Adults have a mean length of $10.2 \mathrm{~mm}$ and an average width of $4.7 \mathrm{~mm}$ (Table II; Fig. 2). Upon reaching the adult phase they weighed $101.0 \mathrm{mg}$ on average $(\mathrm{n}=25)$.

Pardo-Locarno et al. (2006) reported that third instar larvae of $L$. femoratus varied in length from 18 to $21 \mathrm{~mm}$ and in width from 4 to $5 \mathrm{~mm}$, and width of the head capsules ranged from 3 to $3.2 \mathrm{~mm}$. Puker et al. (2009) found that adults of $L$. dorsalis measured on average $10.5 \mathrm{~mm}$ long by $4.6 \mathrm{~mm}$ wide. Rodrigues et al. (2010a) observed that males of L. dorsalis were on average $10.1 \mathrm{~mm}$ long by $4.5 \mathrm{~mm}$ wide, whereas females measured on average $11.0 \mathrm{~mm}$ long by $4.7 \mathrm{~mm}$ wide.

The pre-pupal phase of $L$. alvarengai was characterized by the end of feeding on roots of the larvae, slowing their movement in the soil. When becoming pre-pupae the larvae construct a pupal chamber in the soil formed of soil and probably saliva, which measure on average $8.7 \times 14.2 \mathrm{~mm}(\mathrm{n}=$ 19). In this stage the larvae also presented a grayish-white color.

Santos \& Avila (2009) observed that before becoming pre-pupae the larvae of Liogenys suturalis Blanchard, 1851 constructed a shelter in the soil. Rodrigues et al. (2008) reported that pre-pupae of Anomala testaceipennis Blanchard, 1856 built pupal chambers of soil and saliva, which had average dimensions of $9 \times 25 \mathrm{~mm}$.

In the field collections several orifices in the soil were visualized on various occasions, which had an average diameter of $1.32 \mathrm{~cm}(\mathrm{n}=22)$, and when digging in the soil profile the galleries presented a wavy, unbranched appearance forming angles of $45^{\circ}$ to $75^{\circ}$ relative to the soil surface and had depths of $70-80 \mathrm{~cm}(\mathrm{n}=22)$. At the end of these galleries adults of $L$.

Table I. Duration (mean $\pm \mathrm{SE}$ ) of the development phases of Leucothyreus alvarengai Frey and Leucothyreus aff. semipruinosus Ohais in the laboratory.

\begin{tabular}{|c|c|c|c|c|c|c|c|c|}
\hline \multirow{2}{*}{ Phase } & \multicolumn{4}{|c|}{ Leucothyreus alvarengai } & \multicolumn{4}{|c|}{ Leucothyreus aff. semipruinosus } \\
\hline & Duration (days) & $\mathrm{N}$ & Variation interval & Variability $(\%)$ & Duration (days) & $\mathrm{N}$ & Variation interval & Variability (\%) \\
\hline $2^{\text {nd }}$ instar & $37.3 \pm 1.98$ & 63 & $29-52$ & 91.3 & $32.0 \pm 1.96$ & 30 & $29-41$ & 96.8 \\
\hline $3^{\text {rd }}$ instar & $53.3 \pm 3.13$ & 47 & $41-72$ & 74.6 & $55.1 \pm 2.79$ & 26 & $41-72$ & 86.7 \\
\hline Pre-pupal & $55.0 \pm 1.78$ & 37 & $52-60$ & 78.7 & $64.3 \pm 3.83$ & 20 & $37-98$ & 76.9 \\
\hline Pupal & $24.2 \pm 3.77$ & 32 & $14-37$ & 86.5 & $25.9 \pm 1.72$ & 18 & $17-37$ & 90.0 \\
\hline Adult & $23.6 \pm 1.32$ & 25 & $14-30$ & 78.1 & $27.1 \pm 2.86$ & 15 & $17-41$ & 83.3 \\
\hline $2^{\text {nd }}$ instar to adult & $182.9 \pm 7.52$ & 25 & $165-192$ & 39.7 & $201.1 \pm 9.82$ & 13 & $192-237$ & 43.3 \\
\hline
\end{tabular}

Table II. Average ( \pm SE) body length and width of the development phases of Leucothyreus alvarengai Frey and Leucothyreus aff. semipruinosus Ohaus in the laboratory.

\begin{tabular}{|c|c|c|c|c|c|c|c|c|c|c|c|c|}
\hline \multirow{3}{*}{ Phase } & \multicolumn{6}{|c|}{ Leucothyreus alvarengai } & \multicolumn{6}{|c|}{ Leucothyreus aff. semipruinosus } \\
\hline & \multicolumn{3}{|c|}{ Length (mm) } & \multicolumn{3}{|c|}{ Width (mm) } & \multicolumn{3}{|c|}{ Length (mm) } & \multicolumn{3}{|c|}{ Width (mm) } \\
\hline & Mean + SE & $\mathrm{N}$ & Range & Mean + SE & $\mathrm{N}$ & Range & Mean + SE & $\mathrm{N}$ & Range & Mean + SE & $\mathrm{N}$ & Range \\
\hline $2^{\text {nd }}$ instar & $16.8 \pm 0.65$ & 63 & $12.2-19.7$ & $3.6 \pm 0.13$ & 63 & $2.4-5.0$ & $17.2 \pm 0.23$ & 30 & $12.9-21.9$ & $3.7 \pm 0.08$ & 30 & $2.4-4.7$ \\
\hline $3^{\text {rd }}$ instar & $22.9 \pm 0.28$ & 47 & $16.9-31.8$ & $4.7 \pm 0.09$ & 47 & $3.9-7.7$ & $24.6 \pm 0.77$ & 26 & $20.2-42.9$ & $5.0 \pm 0.16$ & 26 & $3.9-7.9$ \\
\hline Pupal & $11.8 \pm 0.52$ & 32 & $10.5-12.7$ & $5.3 \pm 0.13$ & 32 & $5.0-5.6$ & $12.4 \pm 0.30$ & 18 & $10.8-13.7$ & $5.6 \pm 0.19$ & 18 & $4.2-6.4$ \\
\hline Adult & $10.2 \pm 0.12$ & 25 & $10.0-10.4$ & $4.7 \pm 0.12$ & 25 & $4.5-4.9$ & $11.2 \pm 0.37$ & 15 & $9.1-14.9$ & $5.1 \pm 0.18$ & 15 & $4.1-6.0$ \\
\hline
\end{tabular}


alvarengai were encountered $(\mathrm{n}=5)$, which in turn were located in a chamber with average internal dimensions of 4.0 $\mathrm{cm}$ long by $3.6 \mathrm{~cm}$ wide and $2.8 \mathrm{~cm}$ high $(\mathrm{n}=20)$.

Leuchotyreus alvarengai upon reaching the pre-pupal phase probably migrated in the soil and constructed a chamber, where they turn into pupa and then reach the adult stage. When they detect suitable conditions they migrate to the soil surface and begin their reproductive activities.

Biological aspects of Leucothyreus aff. semipruinosus. Adult emergence began in September and lasted until February when they are still encountered. During the same period the occurrence of eggs was also observed in the dissected females. Both the occurrence of adults and appearance of the first eggs coincide with the beginning of the rainy season in the region (Fig. 5).

First instar larvae are encountered from October to March in the field, and second instar larvae from October to April (Fig. 5). The cycles of the first and second instar larvae coincide with that of soybeans and a portion of the corn crop culture. Third instar larvae can also be sampled in the field beginning in December and finishing their cycle at the end of June, while the pupal phase begins in June and extends until October (Fig. 5). Third instar larvae are sampled at the end of the soybean cycle and practically during the entire corn cycle.

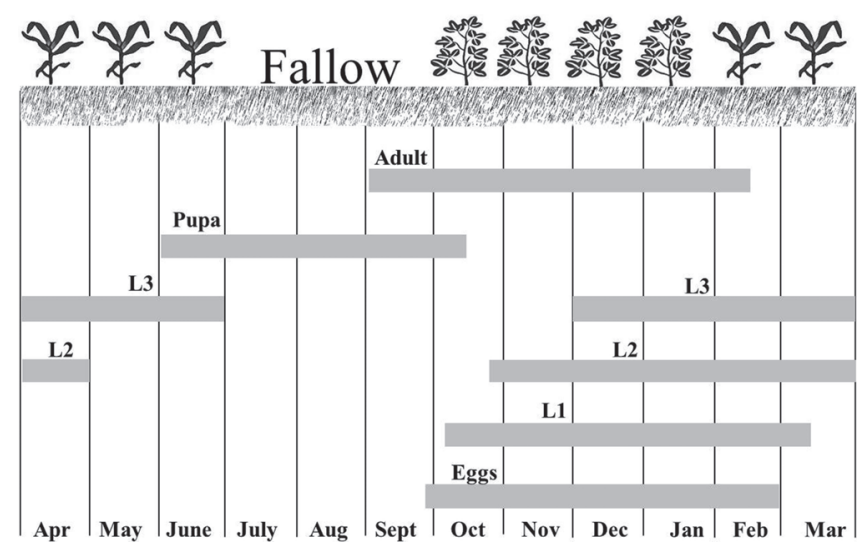

Fig. 5. Seasonality of development phases of Leucothyreus aff. semipruinosus Ohaus in crop succession between April 2011 and March 2012 in Tangará da Serra, Mato Grosso, Brazil.

First instar larvae did not survive in the laboratory, therefore their duration in days was not obtained. Second instar larvae of $L$. aff. semipruinosus remained for roughly 32.0 days in this phase (Table I). Third instar larvae remained for 55.1 days on average in this phase. The pre-pupal phase had a duration of 64.3 days on average. The pupal phase lasted for 25.9 days, where in this phase they obtain the clear yellow color at the beginning of development, and brown at the end of this phase. The adult phase of $L$. aff. semipruinosus lasted 27.1 days on average and the biological cycle was completed in 201.1 days (Table I).
The mean width of the head capsule of second instar larvae was $2.9 \mathrm{~mm}(\mathrm{n}=30)$ and that of the third instar of 4.1 $\mathrm{mm}(\mathrm{n}=26)$. Thus, a 1.4 times increase in width of the head capsule was observed. In second instar, the larvae of $L$. aff. semipruinosus measured $17.2 \mathrm{~mm}$ in length and $3.7 \mathrm{~mm}$ in width on average, and the third instar larvae presented mean length of $24.6 \mathrm{~mm}$ and width of 5.0 (Table II). Growth observed in length and width from the second to third instar stages for larvae of $L$. aff. semipruinosus was 1.4 times for both. Larvae of $L$. aff. semipruinosus in the pre-pupal phase weighted $344.8 \mathrm{mg}(\mathrm{n}=20)$, and when reaching the pupal phase the mean weight was $257.4 \mathrm{mg}(\mathrm{n}=18)$. Pupae of $L$. aff. semipruinosus have $12.4 \mathrm{~mm}$ and $5.6 \mathrm{~mm}$ in length and width, respectively (Table II). Adults measured $11.2 \mathrm{~mm}$ in length and $5.1 \mathrm{~mm}$ in width, with mean weight of $139.2 \mathrm{mg}$ $(\mathrm{n}=15)$ (Table II; Fig. 3).

When monitoring the development phases of $L$. dorsalis, Rodrigues et al. (2010a) reported that the second and third instar lasted 38.9 and 52.7 days, respectively, while the prepupal, pupal and adult phases lasted on average 130.7, 23.5 and 18 days, respectively. Larvae of L. dorsalis observed by Rodrigues et al. (2010a) presented head capsule widths of both the second $(1.8 \mathrm{~mm})$ and third instar $(2.8 \mathrm{~mm})$ smaller than the larvae of $L$. alvarengai and L. aff. semipruinosus.

Pre-pupae of $L$. aff. semipruinosus presented alterations in their color, acquiring a clear yellow color due to the accumulation of fat before the pupal phase. Moreover, at this moment the larvae stopped feeding and became pre-pupae. They constructed a chamber for protection in the soil where they completed their development, the chambers measuring $9.3 \mathrm{~mm}$ in width by $16.4 \mathrm{~mm}$ in length $(\mathrm{n}=10)$. The protection chambers were observed when removing the larvae from the rearing recipients for measurement, and these were formed of soil and saliva and were not easily broken when measured.

Puker et al. (2009) verified that larvae of $L$. dorsalis constructed a pupal chamber with internal dimensions of $26.1 \mathrm{~mm}$ in length by $8.2 \mathrm{~mm}$ in width before becoming pupa. Santos \& Ávila (2009) observed that larvae of L. suturalis altered their color in the final phase of larval development. In the studies of Rodrigues et al. (2010b) it was observed that larvae of Cyclocephala verticalis Burmeister, 1847, before becoming pupae, construct a chamber in the soil for protection and remain there until becoming adult. It is noted that pupae of $L$. aff. semipruinosus were 1.3 times heavier than the pupae of $L$. alvarengai, just as adults of $L$. aff. semipruinosus were 1.4 times heavier than adults of L. alvarengai.

\section{ACKNOWLEDGEMENTS}

To the Coordination for the Improvement of Higher Education Personnel (CAPES) and the Foundation for Supporting the Development of Teaching, Science and Technology of the State of Mato Grosso do Sul (FUNDECT) for the scholarship provided to the first author. To the National Council for Scientific and Technological Development (CNPq) for the financial support.

Revista Brasileira de Entomologia 57(3): 323-328, September 2013 


\section{REFERENCES}

Coutinho, G.V., Rodrigues, S.R., Cruz, E.C. da \& Abot, A.R. 2011. Bionomic data and larval density of Scarabaeidae (Pleurosticti) in sugarcane in the central region of Mato Grosso do Sul, Brazil. Revista Brasileira de Entomologia 55:389-395.

Jameson, M.L. \& Hawkins, S.J. 2005. Synopsis of the genera of Geniatini (Coleoptera: Scarabaeidae: Rutelinae) with an annotated catalog of species. Zootaxa 874: 1-76.

Maman, A.P., Silva, C.J., Sguarezi, E.M. \& Bleich, M.E. 2007. Produção e acúmulo de serapilheira e decomposição foliar em Mata de Galeria e Cerradão no sudoeste de Mato Grosso. Revista de Ciências AgroAmbientais 5: 71-84.

Oliveira, C.M., Morón, M.A. \& Frizzas, M.R. 2007. First record of Phyllophaga sp aff. capillata (Coleoptera: Melolonthidae) as a soybean pest in the Brazilian "Cerrado". Florida Entomologist 90: $772-775$.

Oliveira, C.M., Morón, M.A. \& Frizzas, M.R. 2008. Aegopsis bolboceridus (Coleoptera: Melolonthidae): an important pest on vegetables and corn in Central Brazil. Florida Entomologist 91: 324-327.

Oliveira, L.J., Garcia, M.A., Hoffmann-Campo, C.B., Sosa-Gomez, D.R., Farias, J.R.B. \& Corso, I.C. 1997. Coró-da-soja Phyllophaga cuyabana. Ficha Técnica 20. Londrina, Embrapa-CNPSo, 30 p.

Oliveira, L.J., Hoffmann-Campo, C.B. \& Garcia, M.A. 2000. Effect of soil management on the white grub population and damage in soybean. Pesquisa Agropecuária Brasileira 35: 887-894.

Oliveira, L.J., Santos, B., Parra, J.R.P. \& Hoffmann-Campo, C.B. 2004. Coró-da-soja, p. 167-190. In: Salvadori, J.R., Àvila, C.J. \& Silva, M.T.B. (Ed.). Pragas de solo no Brasil. Passo Fundo: Embrapa-CNPT; Dourados: Embrapa-CPAO; Cruz Alta: Fundacep Fecotrigo, 544p.

Pardo-Locarno, L.C., Montoya-Lerma, J., Bellotti, A.C. \& Schoonhoven, A.V. 2005. Structure and composition of the white grub complex (Coleoptera: Scarabaeidae) in agroecological systems of northern Cauca, Colombia. Florida Entomologist 88: 355-363.

Pardo-Locarno, L.C., Morón, M.A. \& Montoya-Lerma, J. 2006. Descripción de los estados inmaduros de Leucothyreus femoratus
Burmeister (Coleoptera: Melolonthidae: Rutelinae: Geniatini) con notas sobre su biología e importancia agrícola en Colombia. Folia Entomológica Mexicana 45: 179-193.

Puker, A., Rodrigues, S.R., Tiago, E.F. \& Santos, W.T. 2009. Espécies de Scarabaeidae fitófagos (Insecta: Coleoptera) associadas ao sistema radicular de Acrocomia aculeata (Jacq.) Lodd. Ex Mart. (Arecaceae). Biota Neotropica 9: 105-109.

Puker, A., Morón, M.A., Oliveira Junior, O. \& Message, D. 2011. First record of Leucothyreus albopilosus (Coleoptera: Scarabaeidae: Rutelinae: Geniatini) in lesions on stem of Eucalyptus citriodora and beehives of Apis mellifera. Entomological Science: 1-4.

Rodrigues, S.R., Puker, A., Abot, A.R., Barbosa, C.L., Ide, S. \& Coutinho, G.V. 2008. Ocorrência e aspectos biológicos de Anomala testaceipennis Blanchard (Coleoptera, Scarabaeidae). Revista Brasileira de Entomologia 52: 68-71.

Rodrigues, S.R., Puker, A. \& Tiago, E.F. 2010a. Aspectos biológicos de Leucothyreus dorsalis Blanchard (Coleoptera, Scarabaeidae, Rutelinae). Revista Brasileira de Entomologia 54: 431-435.

Rodrigues, S.R., Nogueira, G.A.L., Echeverria, R.R. \& Oliveira, V.S. 2010b. Aspectos biológicos de Cyclocephala verticalis Burmeister (Coleooptera: Scarabaeidae). Neotropical Entomology 39: 15-18.

Rodrigues, S.R., Carmo, J.I., Oliveira, V.S., Tiago, E.F. \& Taira, T.L. 2011. Ocorrência de larvas de Scarabaeidae fitófagos (Insecta: Coleoptera) em diferentes sistemas de sucessão de culturas. Pesquisa Agropecuária Tropical 41: 87-93.

Santos, V. \& Ávila, C.J. 2007. Aspectos bioecológicos de Cyclocephala forsteri Endrodi, 1963 (Coleoptera: Melolonthidae) no estado do Mato Grosso do Sul. Revista de Agricultura 82: 298-303.

Santos, V. \& Ávila, C.J. 2009. Aspectos biológicos e comportamentais de Liogenys suturalis Blanchard (Coleoptera: Melolonthidae) no Mato Grosso do Sul. Neotropical Entomology 38: 734-740.

Silva, M.T.B. \& Grützmacher, A.D. 1996. Biometria de Diloboderus abderus (Sturm) (Coleoptera: Melolonthidae) coletado em solo manejado no sistema de plantio direto. Anais da Sociedade Entomológica do Brasil 25: $377-382$.

Silva, M.T.B. \& Costa, E.C. 2002. Nível de controle de Diloboderus abderus em aveia preta, linho, milho e girassol. Ciência Rural 32: 7-12.

Received 13 November 2012; accepted 9 August 2013

Associate Editor: Lucia M. Almeida 